\title{
Changes in nitrogen budget and potential risk to the environment over 20 years (1990-2010) in the agroecosystems of the Haihe Basin, China
}

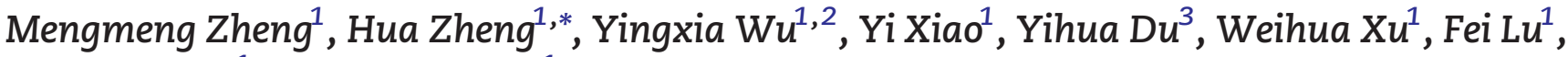 \\ Xiaoke Wang ${ }^{1}$, Zhiyun Ouyang ${ }^{1}$ \\ 1. State Key Laboratory of Urban and Regional Ecology, Research Center for Eco-Environmental Sciences, Chinese Academy of Sciences, \\ Beijing 100085, China. E-mail: mengmeng.zheng@163.com \\ 2. Wuhan University of Technology, Wuhan 430070, China \\ 3. Computer Network Information Center, Chinese Academy of Sciences, Beijing 100190, China
}

\section{A R T I C L E I N F O}

Article history:

Received 18 March 2014

Revised 28 May 2014

Accepted 13 June 2014

Available online 26 December 2014

\section{Keywords:}

Nitrogen budget

Nitrogen surplus intensity

Nitrogen use efficiency

Environmental risk

Agroecosystem

Haihe Basin

\begin{abstract}
A B S T R A C T
The nitrogen balance can serve as an indicator of the risk to the environment of nitrogen loss from agricultural land. To investigate the temporal and spatial changes in agricultural nitrogen application and its potential threat to the environment of the Haihe Basin in China, we used a database of county-level agricultural statistics to calculate agricultural nitrogen input, output, surplus intensity, and use efficiency. Chemical fertilizer nitrogen input increased by $51.7 \%$ from 1990 to 2000 and by $37.2 \%$ from 2000 to 2010, concomitant with increasing crop yields. Simultaneously, the nitrogen surplus intensity increased by 53.5\% from 1990 to 2000 and by $16.5 \%$ from 2000 to 2010, presenting a continuously increased environmental risk. Nitrogen use efficiency decreased from 0.46 in 1990 to 0.42 in 2000 and remained constant at 0.42 in 2010, partly due to fertilizer composition and type improvement. This level indicates that more than half of nitrogen inputs are lost in agroecosystems. Our results suggest that although the improvement in fertilizer composition and types has partially offset the decrease in nitrogen use efficiency, the environmental risk has still increased gradually over the past 20 years, along with the increase in crop yields and nitrogen application. It is important to achieve a better nitrogen balance through more effective management to significantly reduce the environmental risk, decrease nitrogen surplus intensity, and increase nitrogen use efficiency without sacrificing crop yields.
\end{abstract}

(c) 2014 The Research Center for Eco-Environmental Sciences, Chinese Academy of Sciences.

Published by Elsevier B.V.

\section{Introduction}

Nitrogen $(\mathrm{N})$ plays an important role in crop production. Total consumption of world fertilizer $\mathrm{N}$ has increased from $76.8 \mathrm{Tg}$ $\left(1 \mathrm{Tg}=10^{12} \mathrm{~g}\right.$ ) in 1990 to $104.3 \mathrm{Tg}$ in 2010, with China, India, and the United States occupying the top three slots (Heffer, 2013). China consumed 19.2 Tg N of chemical fertilizer in 1990, a fourth of the world's total amount, and $32.6 \mathrm{Tg}$ in 2010, about one-third of the world's total (Guo et al., 2012). Nitrogen inputs into agroecosystems have helped to improve world crop productivity and can enhance economic development (Vitousek et al., 2009), but surplus $\mathrm{N}$ has also led to a host of environmental problems, ranging from eutrophication in terrestrial and aquatic systems to global acidification (Nicolas and Galloway, 2008; Ping et al., 2014).

The nitrogen balance for agricultural land is defined as the difference between the total quantity of $\mathrm{N}$ inputs, including

\footnotetext{
* Corresponding author. E-mail: zhenghua@rcees.ac.cn (Hua Zheng).
} 
inorganic fertilizers, livestock manure, biological nitrogen fixation, and atmospheric deposition and the quantity of outputs, including uptake by harvested food and fodder crops and pasture (OECD, 2008). This balance is one of the key indicators for agricultural $\mathrm{N}$ management. Nitrogen balance analysis is useful not only for predicting $\mathrm{N}$ accumulation in an ecosystem but also for improving nitrogen use efficiency and reducing the environmental risk of $\mathrm{N}$ loss. It has been widely adopted in the transition toward more sustainable agriculture practices (Öborn et al., 2003; Oenema et al., 2003).

To understand nitrogen use efficiency and assess the environmental risk of fertilizer $\mathrm{N}$ application, $\mathrm{N}$ budgets have been estimated in many countries (Breemen et al., 2002; Liu et al., 2008; Atsushi et al., 2009) at various scales, including by country, watershed, region, and worldwide (Sun et al., 2008; Junko, 2012). These estimates have contributed to agricultural $\mathrm{N}$ management to minimize environmental degradation while maintaining high crop yields (Liu and Chen, 2007). Many case studies have focused on particular ecosystems, such as greenhouses, the fields of smallholder farms, and different types of vegetable fields (Wang et al., 2008; Hou et al., 2012). However, spatial differences in $\mathrm{N}$ balance and $\mathrm{N}$ budget changes over time have rarely been addressed at a regional scale, particularly in China (Liu et al., 2008).

The Haihe Basin is one of the important grain production bases in China. Due to agricultural development and the overuse of $\mathrm{N}$ fertilizer, water shortages and water pollution have become very serious problems in the Haihe Basin, which has been one of the most polluted regions in China (Chen et al., 2005; Liu et al., 2010; Wu et al., 2011). A survey of groundwater nitrate-N concentrations in the Haihe Basin showed that approximately $45 \%$ of 600 groundwater samples exceeded $11.3 \mathrm{mg} \mathrm{NO}_{3}-\mathrm{N} / \mathrm{L}(50 \mathrm{mg} \mathrm{NO}-\mathrm{N} / \mathrm{L})$, the World Health Organization's and Europe's limit for nitrate in drinking water. The highest nitrate-N concentration reached $113 \mathrm{mg} / \mathrm{L}$ (Zhang et al., 2004).

We examined the $\mathrm{N}$ balance in this region to determine the characteristics of $\mathrm{N}$ balance, nitrogen use efficiency, and nitrogen surplus intensity, as well as their change trends in the Haihe Basin. We also examined the potential environmental risks of current crop $\mathrm{N}$ management practices and their change trends. We approached these questions by calculating agricultural $\mathrm{N}$ input, output surplus intensity, and use efficiency by using a database of county-level agricultural statistics. The data in the database were collected every 10 years, and we used data from 1990, 2000, and 2010.

\section{Materials and methods}

\subsection{Study area}

The Haihe Basin, which is located in northern China $\left(112-120^{\circ} \mathrm{E}\right.$, $\left.35-43^{\circ} \mathrm{N}\right)$, encompasses all of Beijing and Tianjin, the vast majority of Hebei Province, the eastern part of Shanxi Province, and the northern parts of Henan and Shandong provinces, as well as a small part of the Inner Mongolia Autonomous Region and Liaoning Province. There are 312 counties in the Haihe Basin and the total area is $3.18 \times 10^{5} \mathrm{~km}^{2}$ (Fig. 1). In 2010, the total population was $1.40 \times 10^{8}$ and the cultivated land accounted for $1.29 \times 10^{7}$ ha in the Haihe Basin. The predominant climate is the Asian monsoon climate, with average annual precipitation of $539 \mathrm{~mm}$ and average annual temperatures of $1.5^{\circ} \mathrm{C}-14.0^{\circ} \mathrm{C}$.

The Haihe Basin is one of the top three grain production bases in China. Its grain yield accounts for more than $10 \%$ of the country's total grain yield. In addition, the Haihe Basin is a "vegetable basket" production base for mega cities (Beijing, Tianjing, etc.). To yield sufficient food to feed the increasing

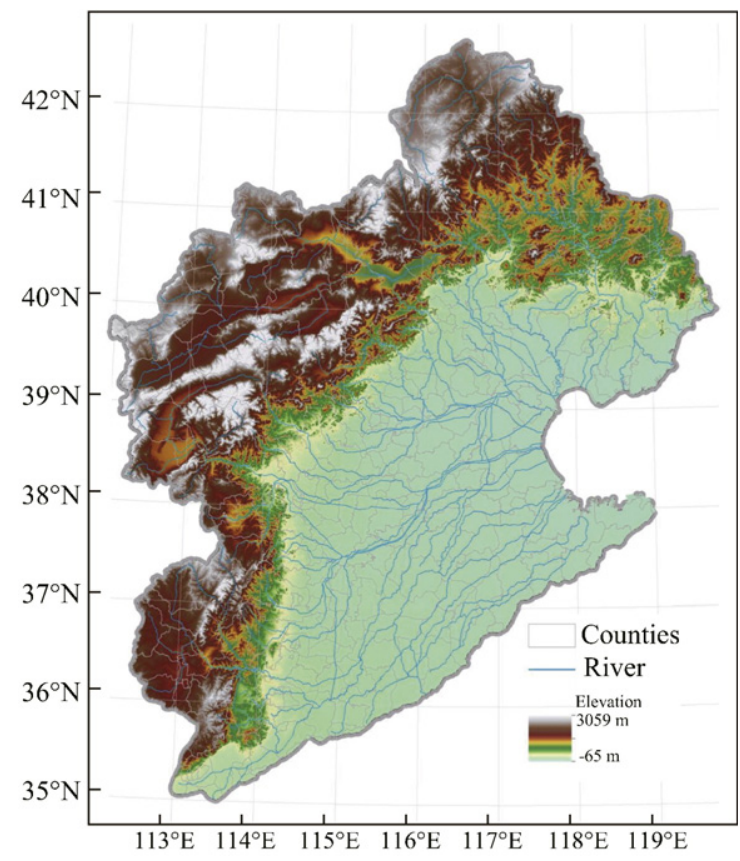

Fig. 1 - The location of the Haihe Basin in China.

population, chemicals, dominated by $\mathrm{N}$ fertilizer, are widely used in the Haihe Basin to boost agricultural productivity (Zhang et al., 2012). Their use makes the Haihe Basin one of the most polluted regions in China. A survey of the $\mathrm{NO}_{3}-\mathrm{N}$ concentrations of shallow groundwater in the North China Plain indicated that approximately $21.5 \%$ of the total surface area of the plain had $\mathrm{NO}_{3}-\mathrm{N}$ levels above $10 \mathrm{mg} / \mathrm{L}$ (Li et al., 2001). Groundwater $\mathrm{NO}_{3}-\mathrm{N}$ increased significantly as the $\mathrm{N}$ fertilization rate increased (Zhao et al., 2007), and the overuse of $\mathrm{N}$ fertilizer was the principal factor affecting groundwater nitrate pollution (Chen et al., 2005).

\subsection{County-level database}

We created a county-level database by using the ArcGIS software developed by ESRI. First, we collected county-level agricultural data recorded in 1990, 2000 and 2010 from the Chinese Academy of Agricultural Sciences, including fertilizer type and amount, crop type (wheat, maize, rice, etc.) and yields, cultivated land area, paddy land area, upland area, irrigation acreage, livestock type (pigs, sheep, cattle, etc.) and amount, etc. Second, we used GIS software to generate the spatial data. For example, average annual precipitation data recorded between 1990 and 2010 at 104 monitoring stations of China Meteorological Administration located in the Haihe Basin were utilized in atmospheric wet deposition calculations to produce county-level data with the kriging method. Finally, the $\mathrm{N}$ input and output were calculated at the county level. A total of 312 county units were used to aggregate various budgets in 1990, 2000 and 2010 in the Haihe Basin based on the above data.

\subsection{Nitrogen balance calculation}

The annual $\mathrm{N}$ balance followed the definition used by the Organisation for Economic Cooperation and Development (2008) 
and was calculated as the difference between $\mathrm{N}$ inputs and outputs for the agroecosystems at the county level in our study.

\subsubsection{Nitrogen input calculation}

Quantified $\mathrm{N}$ inputs include $\mathrm{N}$ in chemical fertilizer, irrigation water, atmospheric bulk (wet/dry) deposition, $\mathrm{N}$ supplied by biofixation, and organic N (human excreta, livestock excreta, and crop straw recycled as manure). These inputs are calculated using Eq. (1).

$\begin{aligned} \mathrm{N}_{\text {input }}= & \mathrm{N}_{\text {chemical }}+\mathrm{N}_{\text {irrigation }}+\mathrm{N}_{\text {atmospheric }}+\mathrm{N}_{\text {biofixation }} \\ & +\mathrm{N}_{\text {human }}+\mathrm{N}_{\text {livestock }}+\mathrm{N}_{\text {straw }}\end{aligned}$

1.3.1.1. Chemical fertilizer $\left(N_{\text {chemical }}\right)$ and irrigation $\left(N_{\text {irrigation }}\right)$. Pure $\mathrm{N}$ fertilizer and $\mathrm{N}$ in compound fertilizer were used for chemical $\mathrm{N}$ fertilizer in our study. As presented by Li and Jin (2011), 35\% was used for the average $\mathrm{N}$ content of compound fertilizer. Uplands accounted for $99 \%$ of the agricultural land in our study area. Based on the acreage of irrigation and the irrigation $\mathrm{N}$ input, $16 \mathrm{~kg} \mathrm{~N} / \mathrm{ha} / \mathrm{yr}$ (5-28.7 kg N/ha/yr) presented by Li and Jin (2011), we calculated the annual $\mathrm{N}$ input from irrigation ( $\mathrm{N}_{\text {irrigation}}$ ).

1.3.1.2. Atmospheric bulk (wet/dry) deposition ( $N_{\text {atmospheric }}$. The annual $\mathrm{N}$ input from atmospheric wet/dry deposition ( $\mathrm{N}_{\text {atmospheric }}$ ) for each county is affected by three factors: the arable land area, the annual precipitation, and the bulk $\mathrm{N}$ concentration of the precipitation of each county. The arable land area was collected from county-level statistics data. Annual precipitation data were available 1990-2010 at 104 monitoring stations located in the Haihe Basin. Then the annual precipitation point values were kriged to create a spatial map. After we overlaid county boundaries, the annual precipitation was aggregated to the county scale by using the ARCGIS software. According to the monitoring results in North China presented by Zhang et al. (2008), the mean volumeweighted bulk $\mathrm{N}$ concentrations in precipitation were $3.9 \mathrm{mg} / \mathrm{L}$ (2.1-5.9 mg/L) in the 1990s and $5.4 \mathrm{mg} / \mathrm{L}(2.2-7.5 \mathrm{mg} / \mathrm{L})$ between 2000 and 2010.

1.3.1.3. Biological $N$ fixation $\left(N_{\text {biofixation }}\right)$. The main source of biological $\mathrm{N}$ fixation is the growing of legumes, such as soybean and peanut (Chen et al., 2008). $\mathrm{N}$ inputs from biological fixation considered both symbiotic $\mathrm{N}$-fixation crops (peanut and soybean only, as the area in which other symbiotic $\mathrm{N}$-fixation crops were cultivated was very small in the Haihe Basin) and nonsymbiotic $\mathrm{N}$-fixation crops in wheat plantations and other cropland areas, such as rice fields. The annual $\mathrm{N}$ input from biological $\mathrm{N}$ fixation ( $\mathrm{N}_{\text {biofixation}}$ ) was the sum of the biofixation $\mathrm{N}$ quantity of four types of crops or fields, and $\mathrm{N}$ input from the biological $\mathrm{N}$ fixation of each type of crop or field was the product of the sowing area of each crop and the relevant $\mathrm{N}$-fixation rates. The average $\mathrm{N}$-fixation rates of each crop adopted in our study are based on parameters from Li and Jin (2011), Zhao et al. (2009a), and Hu et al. (2011).

1.3.1.4. Organic $N$ ( $N_{\text {human }}, N_{\text {livestock, }}$ and $\left.N_{\text {straw }}\right)$. Organic $N$ inputs were the sum of $\mathrm{N}$ in human excreta, livestock excreta, and crop straw recycled as manure. The annual $\mathrm{N}$ input from human manure ( $\mathrm{N}_{\text {human }}$ ) was the product of the rural population quantity, the return value of human excretion $\mathrm{N}$ to arable land (0.69 kg N/(head·year)), and a conversion coefficient, 0.85 , that translated the total rural population to the rural adult population (Xing and Zhu, 2002). The annual $\mathrm{N}$ input from each type of livestock (e.g., cattle, pigs, sheep) manure was the product of the number of animals, the mean annual $\mathrm{N}$ excretion amount of a single animal (Wang et al., 2006), and the return ratio of livestock excretion (Li and Jin, 2011). We added the products of cattle, pig, and sheep manure to obtain the annual $\mathrm{N}$ input from livestock manure ( $\mathrm{N}_{\text {livestock }}$ ). The annual $\mathrm{N}$ input from each type of crop (e.g., wheat, maize, rice) straw returned to the field was the product of the N content in crop straw (\%) (Li and Jin, 2011), the return ratio of crop straw (Gao et al., 2009), the ratio between crop straw and crop yield (Bi et al., 2009), and the yield of the crop. The annual $\mathrm{N}$ input from crop straw returned to the field $\left(\mathrm{N}_{\text {straw }}\right)$ was the sum of the products.

\subsubsection{Nitrogen output calculation}

Quantified $\mathrm{N}$ outputs include, in addition to the $\mathrm{N}$ in harvested biomass (including both grain and straw), the $\mathrm{N}$ losses due to volatilization of ammonia, leaching, and denitrification. These items are calculated using Eq. (2).

$\mathrm{N}_{\text {output }}=\mathrm{N}_{\text {harvest }}+\mathrm{N}_{\text {ammonia }}+\mathrm{N}_{\text {leaching }}+\mathrm{N}_{\text {denitrification }}$

1.3.2.1. Nitrogen in the harvested crops ( $\left.N_{\text {harvest }}\right)$. We multiplied a single crop's yield by the crop's $\mathrm{N}$ requirement for unit yield, following Li and Jin (2011) and then added the products of all crops to obtain the total $\mathrm{N}$ in the harvested crops ( $\left.\mathrm{N}_{\text {harvest }}\right)$.

1.3.2.2. Ammonia volatilization ( $\mathrm{N}_{\text {ammonia }}$ ). $\mathrm{N}$ is lost by the volatilization of ammonia $\left(\mathrm{NH}_{3}\right)$ from chemical fertilizers and human and animal manure applied to arable land. The total $\mathrm{N}$ output from $\mathrm{NH}_{3}$ volatilization is the sum of these three sources of gaseous $\mathrm{N}$ loss ( $\mathrm{N}_{\text {ammonia }}$ ). As presented by Hu et al. (2011), 16\% was used for the annual average $\mathrm{NH}_{3}$ volatilization loss rate of chemical fertilizer. We adopted the default value of $20 \%$ presented in the Intergovernmental Panel on Climate Change Guidelines as the $\mathrm{NH}_{3}$ volatilization percentage from human wastes (IPCC, 1996). Many studies have shown that the losses may be as high as $30 \%-40 \%$ of the total $\mathrm{N}$ after the surface application of fresh cattle or pig slurries (Liu et al., 2008). According to the results presented by Liu (2005), 26.2\%, $12.3 \%$, and $16.7 \%$ were used for the fraction of $\mathrm{N}$ that volatilizes as $\mathrm{NH}_{3}$ from pig manure, cattle manure, and sheep manure, respectively.

1.3.2.3. Leaching ( $\left.N_{\text {leaching }}\right)$ and denitrification losses $\left(N_{\text {denitrification }}\right)$. According to many studies in the Haihe Basin (Xing and Zhu, 2002; Ju et al., 2009), $N$ leaching ( $\left.N_{\text {leaching }}\right)$ from uplands in north China accounted for about 5\% (0.5\%-12.1\%) of the applied $N$, which was also used in our study. The chemical fertilizer emission factor in our estimate of $N_{\text {denitrification was determined }}$ according to the results of $2 \%$ in the Haihe Basin presented by Ju et al. (2009) and Hu et al. (2011).

\subsection{Nitrogen surplus intensity and nitrogen use efficiency}

We divided the $\mathrm{N}$ balance value of a county by its arable land area to obtain the $\mathrm{N}$ surplus intensity (NSI). A positive NSI represented a positive $\mathrm{N}$ balance, and vice versa. Nitrogen use 
efficiency (NUE) was defined as the proportion of all $\mathrm{N}$ inputs that are exported via the harvested crop biomass (both grain and straw) (Liu et al., 2008). Using this definition, the percentage value is higher in more efficient systems, because a high NUE value indicates that a larger portion of $\mathrm{N}$ is utilized by the agroecosystems for which all $\mathrm{N}$ inputs are intended. Furthermore, a high NUE indicates that a relatively smaller portion of $\mathrm{N}$ is lost by $\mathrm{NH}_{3}$ volatilization and denitrification to the atmosphere or leaching to groundwater (Nielsen, 2006; Liu et al., 2008).

\section{Results}

\subsection{Agricultural $\mathrm{N}$ application and crop yield}

In the Haihe Basin, chemical fertilizer $\mathrm{N}$ input increased from $149 \mathrm{~kg} /$ ha in 1990 to $310 \mathrm{~kg} / \mathrm{ha}$ in 2010, an increase of 108.1\%. At the same time, the yields of main grain crops (wheat, maize, and rice) increased from $4309 \mathrm{~kg} / \mathrm{ha}$ in 1990 to $6826 \mathrm{~kg} / \mathrm{ha}$ in 2010, an increase of 45.9\% (Fig. 2). Both from 1990 to 2000 and from 2000 to 2010, chemical fertilizer $\mathrm{N}$ input and the main grain crop yield increased continuously.

Fertilizer composition also changed greatly between 1990 and 2010 (Fig. 3). The proportion of chemical fertilizer that was $\mathrm{N}$ decreased from $64 \%$ in 1990 to $45 \%$ in 2010 . During this same time, the proportion of potassium and phosphorus increased from $21 \%$ to $26 \%$, and the proportion of compound fertilizer increased from $16 \%$ to $29 \%$.

\subsection{Agricultural $\mathrm{N}$ input, output, and balance}

Total $\mathrm{N}$ input, including chemical fertilizer, atmospheric deposition, biological fixation, irrigation, human manure, and crop residue, increased from $30.50 \times 10^{8} \mathrm{~kg}$ in 1990 to $54.14 \times 10^{8} \mathrm{~kg}$ in 2010 , or $177.5 \%$ of the 1990 amount. Total $\mathrm{N}$ output, including $\mathrm{N}$ in the harvested crops and $\mathrm{N}$ lost through ammonia volatilization, leaching, and denitrification, also increased from $19.13 \times 10^{8} \mathrm{~kg}$ in 1990 to $33.66 \times 10^{8} \mathrm{~kg}$ in 2010 .

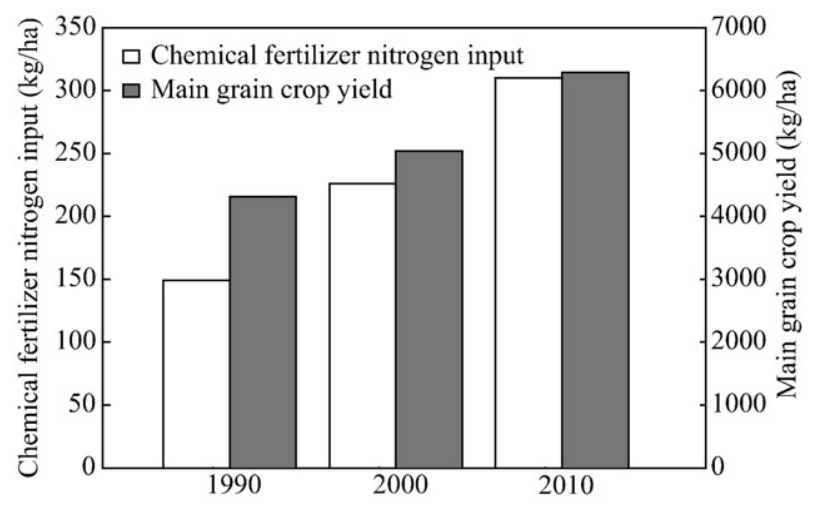

Fig. 2 - Changes in the main grain crop yields and chemical fertilizer nitrogen input between 1990 and 2010 in the Haihe Basin. The main grain crop includes wheat and maize. Chemical fertilizer nitrogen input refers to the total nitrogen applied to wheat, maize, rice, pulses, vegetables, fruit, oil crops, and other crops.

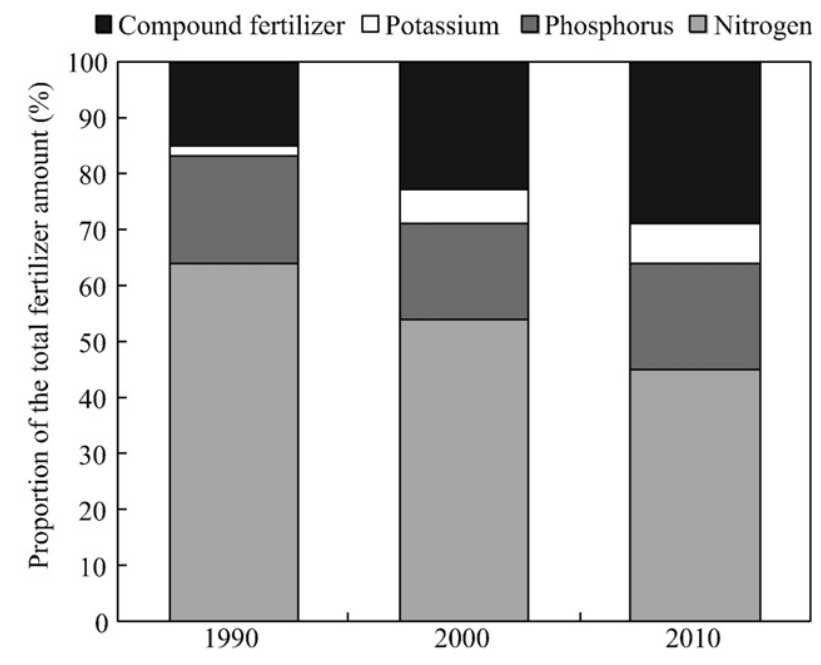

Fig. 3 - Fertilizer composition changes between 1990 and 2010 in the Haihe Basin.

Although both $\mathrm{N}$ input and $\mathrm{N}$ output increased gradually between 1990 and 2010, the $\mathrm{N}$ budget (input-output) also increased from $11.37 \times 10^{8} \mathrm{~kg}$ in 1990 to $20.48 \times 10^{8} \mathrm{~kg}$ in 2010 , an increase of $80.1 \%$. Correspondingly, NSI increased from $88.83 \mathrm{~kg} / \mathrm{ha}$ in 1990 to $158.76 \mathrm{~kg} / \mathrm{ha}$ in 2010 , an increase of $46.9 \%$.

\subsection{Spatial pattern of $N$ surplus intensity}

Trends for $\mathrm{N}$ balance varied widely among counties. Although the NSI did increase over time, the growth rates did not increase as much. In the northeast region of the Haihe Basin, the NSI of most counties increased 50-200 kg N/(ha.year) from 1990 to 2000, but it decreased from 2000 to 2010, thus leading to a lower surplus from 1990 to 2010 . The western region mainly displayed a low surplus from 1990 to 2000, but some counties showed NSI variations corresponding to an increment of $100-200 \mathrm{~kg} \mathrm{~N} /$ (ha.year) from 2000 to 2010. In the southern region, a high NSI center formed during the study period. Another center formed in the mid-eastern region. These regions were important agricultural districts in the Haihe Basin. However, the NSI declined in some counties in the southeast region of the Haihe Basin (Fig. 4).

\subsection{Nitrogen use efficiency}

Fig. 5 shows the relationship between the $\mathrm{N}$ in harvested crops and the total $\mathrm{N}$ inputs in 1990, 2000, and 2010. The total amount of $\mathrm{N}$ in harvested crops has a linear relationship with the total $\mathrm{N}$ inputs. The nitrogen use efficiency decreased from 0.46 in 1990 to 0.42 in 2000, then remained stable at 0.42 between 2000 and 2010 (Fig. 5).

\section{Discussion}

The main grain crop yield in the Haihe Basin increased gradually along with the increase in chemical fertilizer $\mathrm{N}$ input (Fig. 2). The increased fertilizer input probably contributed to the improvement in main grain crop productivity in 


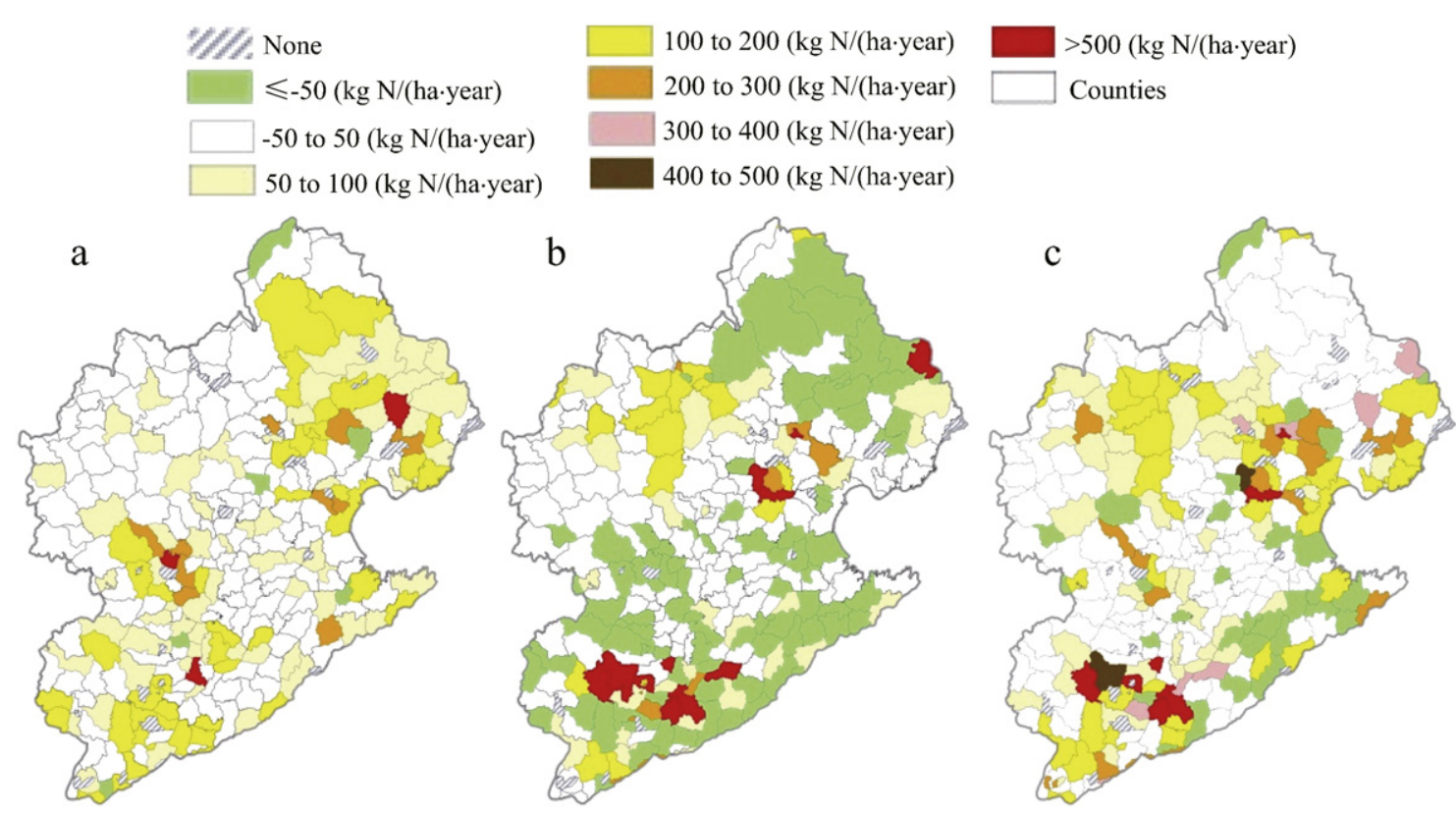

Fig. 4 - Spatial change in nitrogen surplus intensity (a) between 1990 and 2000, (b) between 2000 and 2010, and (c) between 1990 and 2010.

Haihe Basin. However, excessive $\mathrm{N}$ fertilization in intensive agriculture in China has caused serious environmental problems because the atmosphere, soil, and water are enriched with reactive $\mathrm{N}$ of agricultural origin (Ju et al., 2009). In our study, fertilizer $\mathrm{N}$ application increased environmental risk. NSI increased from $88.83 \mathrm{~kg} / \mathrm{ha}$ in 1990 to $158.76 \mathrm{~kg} / \mathrm{ha}$ in 2010 (Table 1), a level that far exceeds that of the Midwestern United States (10 kg N/(ha·year)), Western Kenya (-52 kg N/(ha.year)), or the United Kingdom (51 kg N/(ha·year)) (Baker et al., 2001; Lord et al., 2002; Vitousek et al., 2009). NSI in the Haihe Basin also exceeded the standard limit ( $60 \mathrm{~kg} \mathrm{~N} / \mathrm{ha}$ on sandy soils and $100 \mathrm{~kg} \mathrm{~N} / \mathrm{ha}$ on clay soils) for possible nitrate leaching into ground and surface waters at a regional or national scale (Hou et al., 2012). Groundwater pollution has become much heavier over the past few decades and more than $60 \%$ of rivers have

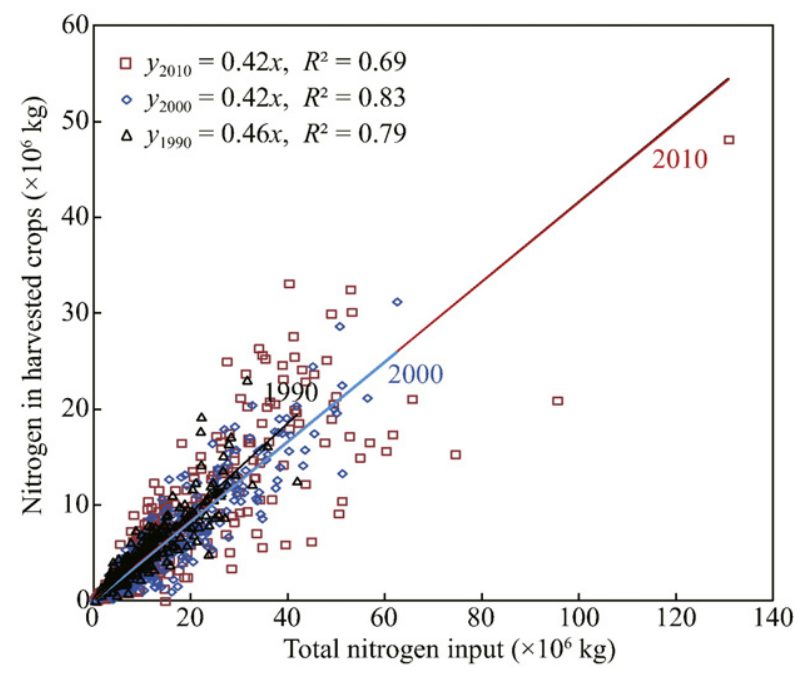

Fig. 5 - Relationship between total nitrogen inputs and nitrogen in harvested crops. become polluted in the Haihe Basin (Ouyang et al., 2013). There is a clear qualitative relationship between $\mathrm{N}$ surplus and nitrate concentrations in the groundwater in a given crop-growing area, meaning that massive $\mathrm{N}$ accumulations in fields are likely to increase the risk of groundwater nitrate contamination (Zhao et al., 2009b; Hou et al., 2012; Chen et al., 2013).

NUE describes the ratio between the amount of fertilizer $\mathrm{N}$ removed from a field by a crop and the amount of fertilizer $\mathrm{N}$ that was originally applied. It provides information about the relative utilization of additional $\mathrm{N}$ applied to the agricultural production system of a country or region. NUE was 0.46 in 1990, 0.42 in 2000, and 0.42 in 2010 (Fig. 5), indicating that more than half of $\mathrm{N}$ inputs are lost in agroecosystems. The results were similar to those reported by Smil (2001), who found that only approximately half of all $\mathrm{N}$ that was applied to cropland as fertilizer is actually recovered in the harvested crops. Excessive use of nitrogenous fertilizer causes eutrophication, loss of diversity, dominance by weedy species, air pollution, water pollution, soil acidification, and emission of the ozone-depleting greenhouse gas nitrous oxide (Ravishankara et al., 2009). Ju et al. (2009) also reported that on the North China Plain, $22 \%-40 \%$ of the $\mathrm{N}$ applied in wheat-maize rotation systems could be emitted via ammonia $\left(\mathrm{NH}_{3}\right)$ volatilization, nitrate leaching, and denitrification.

NUE decreased from 0.46 in 1990 to 0.42 in 2000 between 1990 and 2000 (Fig. 5) with the increase of $\mathrm{N}$ input. However, NUE remained stable between 2000 and 2010 in the Haihe Basin, despite steady increases in chemical fertilization input and NSI. One of the important reasons for its stability is a continuous change in fertilizer composition: the proportion of chemical fertilizer that was $\mathrm{N}$ decreased, and the proportion that was potassium $(\mathrm{K})$ and phosphorus $(\mathrm{P})$ in compound fertilizer increased (Fig. 3). From Africa through Europe and Asia, including China, $\mathrm{P}$ and $\mathrm{K}$ applications in fertilizer are very unbalanced with regard to $N$. Balanced fertilization (particularly that which increases $\mathrm{P}$ and $\mathrm{K}$ application) can 
Table 1 - Changes of agricultural nitrogen input, output and budget between 1990 and 2010 in the Haihe Basin.

\begin{tabular}{|c|c|c|c|}
\hline \multicolumn{4}{|c|}{ Nitrogen input $\left(10^{8} \mathrm{~kg} \mathrm{~N}\right)$} \\
\hline Sources & 1990 & 2000 & 2010 \\
\hline Chemical fertilizer & 19.12 & 30.61 & 39.94 \\
\hline Atmospheric deposition & $2.78(1.50-4.22)$ & $3.84(1.49-4.19)$ & $3.85(1.47-4.12)$ \\
\hline Biological fixation & 2.73 & 2.64 & 1.76 \\
\hline Upland fixation & 0.71 & 0.72 & 0.68 \\
\hline Paddy land fixation & 0.11 & 0.11 & 0.08 \\
\hline Pulse fixation & 1.58 & 1.19 & 0.46 \\
\hline Peanut fixation & 0.33 & 0.63 & 0.54 \\
\hline Irrigation & $1.06(0.33-1.91)$ & $1.2(0.37-2.15)$ & $1.36(0.39-2.21)$ \\
\hline Animal manure & 3.32 & 5.66 & 4.85 \\
\hline Pig manure & 0.27 & 0.62 & 0.86 \\
\hline Sheep manure & 1.13 & 1.84 & 1.52 \\
\hline Cattle manure & 1.92 & 3.2 & 2.47 \\
\hline Human manure & 0.54 & 0.55 & 0.58 \\
\hline Crop residue & 0.94 & 1.19 & 1.8 \\
\hline Wheat & 0.38 & 0.49 & 0.56 \\
\hline Maize & 0.52 & 0.68 & 1.21 \\
\hline Rice & 0.04 & 0.03 & 0.03 \\
\hline Total inputs & 30.5 (28.49-32.79) & $45.7(42.52-47.00)$ & $54.14(50.79-55.26)$ \\
\hline Budget (inputs-outputs) & 11.37 & 18.54 & 20.48 \\
\hline NSI $(\mathrm{kg} / \mathrm{ha})$ & 88.83 & 136.32 & 158.76 \\
\hline $\mathrm{N}$ in the harvested crops & 14.15 & 18.98 & 22.79 \\
\hline Wheat & 4.6 & 5.98 & 6.74 \\
\hline Maize & 4.28 & 5.67 & 9.06 \\
\hline Rice & 0.23 & 0.2 & 0.2 \\
\hline Pulses & 1.76 & 1.31 & 0.63 \\
\hline Vegetables & 0.93 & 3.61 & 4.97 \\
\hline Fruit & 0.68 & 0.32 & 0.54 \\
\hline Oil crops & 0.55 & 1.22 & 0.09 \\
\hline Other crops & 1.12 & 0.67 & 0.56 \\
\hline Ammonia volatilization & 3.65 & 5.98 & 7.83 \\
\hline Chemical fertilizer & 3.05 & 5.01 & 6.95 \\
\hline Human manure & 0.11 & 0.11 & 0.12 \\
\hline Pig manure & 0.07 & 0.16 & 0.2 \\
\hline Sheep manure & 0.19 & 0.31 & 0.25 \\
\hline Cattle manure & 0.23 & 0.39 & 0.31 \\
\hline Leaching & $0.95(0.10-2.30)$ & $1.57(0.16-3.79)$ & $2.17(0.22-5.26)$ \\
\hline Denitrification & 0.38 & 0.63 & 0.87 \\
\hline Total outputs & $19.13(18.28-20.48)$ & $27.16(25.75-29.38)$ & $33.66(31.71-36.75)$ \\
\hline
\end{tabular}

increase crop production, improve nutrient use efficiency, and avoid unnecessary nutrient losses to the environment. For example, wheat and corn yields have increased by $15 \%$ to $20 \%$ in recent years as a result of using balanced fertilization in China (International Fertilizer Industry Association, 2007). The use of compound fertilizer is also an important aspect of balanced fertilization.

Our results showed that the increased fertilizer input and the increased NSI together with low NUE increased the environmental risks gradually, although the improvement in fertilizer composition and types has partially offset the decrease in nitrogen use efficiency (Table 1, Figs. 2, 3, 5). A better $\mathrm{N}$ balance should be achieved in order to significantly reduce environmental risk, without sacrificing crop yields. There are many possible approaches to achieve this goal (Liu and Chen, 2007; Zhao et al., 2007): (1) improving the efficiency of crop absorption and reducing chemical use rates, (2) developing crop varieties that fix $\mathrm{N}$ to reduce fertilizer demand, (3) adjusting the $\mathrm{N}: \mathrm{P}: \mathrm{K}$ ratio to increase crop yield response to fertilizer, (4) employing balanced and integrated use of chemical and organic fertilizers, on the basis of soil tests, and (5) improving farmer knowledge of soil fertility and fertilizer use through better extension and education.

Generally speaking, nutrient budgets for large regions are often very uncertain because it is difficult to accurately measure each component of $\mathrm{N}$ budgets, $\mathrm{N}$ input, and $\mathrm{N}$ output (Sogbedji et al., 2000), such as $\mathrm{N}$ input from atmospheric deposition and biological $\mathrm{N}$ fixation, and $\mathrm{N}$ losses from volatilization, leaching, and runoff (International Fertilizer Industry Association, 2007). Our estimates contain several uncertainties caused by the methodological assumptions as well as the high uncertainties in the research on complex biogeochemical processes. For example, only agricultural land is included in our estimate, although other ecosystems (e.g., forest, grassland, wetland) may influence $\mathrm{N}$ input, output, and storage in agroecosystems. Leaving these other ecosystems out of the analysis may result in a large uncertainty. Furthermore, there are widespread and reliable data on wet and dry deposition, but estimates on $\mathrm{N}$ deposition are highly uncertain (Lu et al., 2013).

Further studies that focus on assessing the impacts of changing farm practices at appropriate scales and on developing incentives to promote the adoption of nutrient-conserving 
practices and processes (Vitousek et al., 2009) are needed. Analyses such as the present one will help to develop and sustain modern agricultural systems without incurring continuing costs to the environment and human health.

\section{Acknowledgments}

This work was supported by the National Natural Science Foundation of China (No. 41371538), international cooperative project of the Chinese Academy of Sciences (No. KZCX2-YW-T13) and the Innovation Project of the State Key Laboratory of Urban and Regional Ecology of China (No. SKLURE2013-1-02).

\section{R E F E R E N C E S}

Atsushi, H., Krishna, P.W., Mariko, S., Koji, N., Kanta, K., Ryusuke, H., 2009. Nitrogen budget and relationships with riverine $\mathrm{N}$ exports of a dairy cattle farming catchment in eastern Hokkaido, Japan. Soil Sci. Plant Nutr. 55 (6), 800-819.

Baker, L.A., Hope, D., Xu, Y., Edmonds, J., Lauver, L., 2001. Nitrogen balance for the Central Arizona-Phoenix (CAP) ecosystem. Ecosystems 4, 582-602.

Bi, Y.Y., Gao, C.Y., Wang, Y.J., Li, B.Y., 2009. Estimation of straw resources in China. Trans. CSAE 25 (12), 211-217.

Breemen, N.V., Boyer, E.W., Goodale, C.L., Jaworski, N.A., Paustian, K., Seitzinger, S.P., et al., 2002. Where did all the nitrogen go? Fate of nitrogen inputs to large watersheds in the northeastern U.S.A. Biogeochemistry 57 (58), 267-293.

Chen, J.Y., Tang, C.Y., Sakura, Y., Yu, J.J., Fukushima, Y., 2005. Nitrate pollution from agriculture in different hydrogeological zones of the regional groundwater flow system in the North China Plain. Hydrogeol. J. 13, 481-492.

Chen, N.W., Hong, H.S., Zhang, L.P., Cao, W.Z., 2008. Nitrogen sources and exports in an agricultural watershed in Southeast China. Biogeochemistry 87, 169-179.

Chen, F.L., Zheng, H., Zhang, K., Ouyang, Z.Y., Li, H.L., Wu, B., Shi, Q., 2013. Soil microbial community structure and function responses to successive planting of eucalyptus. J. Environ. Sci. 25 (10), 2102-2111.

Gao, L.W., Wang, F.H., Ma, L., Zhang, W.F., Ma, W.Q., Zhang, F.S., 2009. Analysis on crop straw resources and its current status of utilization in Hebei Province. J. Anhui Agric. Sci. 37 (23), 11079-11083 (in Chinese).

Guo, L.Y., Yang, R., Wang, D.L., 2012. A study on the spatial difference of farmland nitrogen nutrient budget in the Bohai Rim region, China. J. Geogr. Sci. 22 (4), 761-768.

Heffer, P., 2013. Assessment of fertilizer use by crop at the global level 2010-2010/11. International Fertilizer Industry Association (IFA) 28, rue Marbeuf, 75008 Paris, France.

Hou, Y., Gao, Z.L., Heimann, L., Roelcke, M., Ma, W.Q., Nieder, R., 2012. Nitrogen balances of smallholder farms in major cropping systems in a peri-urban area of Beijing, China. Nutr. Cycl. Agroecosyst. 92, 347-361.

Hu, C.S., Dong, W.X., Zhang, Y.M., Cheng, Y.S., Li, X.X., Yang, L.L., 2011. Nitrogen flux and its manipulation in the cropland ecosystem of the North China Plain. Chin. J. Eco Agric. 19 (5), 997-1003 (In Chinese).

International Fertilizer Industry Association, 2007. Fertilizer Best Management Practices-General Principle Strategy for their Adoption and Voluntary Initiatives vs Regulations. Paris, France. (www.fertilizer.org).

IPCC, 1996. International panel on climate change guidelines for national greenhouse gas inventories. Chapter 4. Agriculture:
Nitrous Oxide from Agricultural Soil and Manure Management. OECD, Paris.

Ju, X.T., Xing, G.X., Chen, X.P., Zhang, S.L., Zhang, L.Y., Liu, X.J., et al., 2009. Reducing environmental risk by improving $\mathrm{N}$ management in intensive Chinese agricultural systems. PNAS 106 (9), 3041-3046.

Junko, S., 2012. Changes in the nitrogen balance in agricultural land in Japan and 12 other Asian countries based on a nitrogen-flow model. Nutr. Cycl. Agroecosyst. 94, 47-61.

Li, S.T., Jin, J.Y., 2011. Characteristics of nutrient input/output and nutrient balance in different regions of China. Sci. Agric. Sin. 44 (20), 4207-4229.

Li, B.G., Bai, Y.L., Hu, K.L., Huang, Y.F., Chen, D.L., 2001. Spatial variability and distribution characteristics of $\mathrm{NO}_{3}-\mathrm{N}$ of shallow ground water in the North China Plain, China. Eng. Sci. 3, 42-45.

Liu, X.L., 2005. Nitrogen Cycling and Balance in "Agriculture-Livestock-Nutrition-Environment" System of China. Master Thesis. Agricultural University of Hebei, Hebei, China.

Liu, X., Chen, B., 2007. Efficiency and sustainability analysis of grain production in Jiangsu and Shaanxi Provinces of China. J. Clean. Prod. 15 (4), 313-322.

Liu, C., Watanabe, M., Wang, Q.X., 2008. Changes in nitrogen budgets and nitrogen use efficiency in the agroecosystems of the Changjiang River basin between 1980 and 2000. Nutr. Cycl. Agroecosyst. 80, 19-37.

Liu, X.B., Li, G.F., Liu, Z.G., Guo, W.H., Gao, N.Y., 2010. Water pollution characteristics and assessment of lower reaches in Haihe river basin. Procedia Environ. Sci. 2, 199-206.

Lord, E.I., Anthony, S.G., Goodlass, G., 2002. Agricultural nitrogen balance and water quality in the UK. Soil Use Manag. 18, 363-369.

Lu, X.H., Jiang, H., Zhang, X.Y., Liu, J.X., Zhang, Z., Jin, J.X., et al., 2013. Estimated global nitrogen deposition using $\mathrm{NO}_{2}$ column density. Int. J. Remote Sens. 34 (24), 8893-8906.

Nicolas, G., Galloway, J.N., 2008. An earth-system perspective of the global nitrogen cycle. Nature 451 (17), 293-296.

Nielsen, R.L., 2006. N loss mechanisms and nitrogen use efficiency. Purdue Nitrogen Management Workshops, pp. 1-5.

Öborn, I., Edwards, A.C., Witter, E., Oenema, O., Ivarsson, K., Withers, P.J.A., et al., 2003. Element balances as a tool for sustainable nutrient management: a critical appraisal of their merits and limitations within an agronomic and environmental context. Eur. J. Agron. 20, 211-225.

OECD, 2008. Environmental Performance of Agriculture in OECD Countries Since 1990. Organisation for Economic Cooperation and Development, Paris, p. 575.

Oenema, O., Kros, H., Vries, W.D., 2003. Approaches and uncertainties in nutrient budgets: implications for nutrient management and environmental policies. Eur. J. Agron. 20, 3-16.

Ouyang, Z.Y., Zheng, H., Peng, S.Z., et al., 2013. Ecosystem Evolution, Ecological Effects and Their Regulation Methods in Haihe Basin. Science Press, Beijing.

Ping, H., Prakash, K., Bee-Lian, O., 2014. Remediation of nutrient-rich waters using the terrestrial plant, Pandanus amaryllifolius Roxb. J. Environ. Sci. 26, 404-414.

Ravishankara, A.R., Daniel, J.S., Portmann, R.W., 2009. Nitrous oxide $\left(\mathrm{N}_{2} \mathrm{O}\right)$ : the dominant ozone-depleting substance emitted in the 21st century. Science 326, 123-125.

Smil, V., 2001. Enriching the Earth:Fritz Haber, Carl Bosch, and Transformation of World Food Production. The MIT Press, Cambridge, MA, USA.

Sogbedji, J.M., vanEs, H.M., Yang, C.L., Geohring, L.D., Magdoff, F.R., 2000. Nitrate leaching and nitrogen budget as affected by maize nitrogen rate and soil type. J. Environ. Qual. 29, 1813-1820.

Sun, B., Shen, R.P., Bouwman, A.F., 2008. Surface N balances in agricultural crop production systems in China for the period 1980-2015. Pedosphere 18 (3), 304-315.

Vitousek, P.M., Naylor, R., Crews, T., David, M.B., Drinkwater, L.E., Holland, E., et al., 2009. Nutrient imbalances in agricultural development. Science 324 (19), 1519-1520. 
Wang, F.H., Ma, W.Q., Dou, Z.X., Ma, L., Liu, X.L., Xu, J.X., et al., 2006. The estimation of the production amount of animal manure and its environmental effect in China. China Environ. Sci. 26 (5), 614-617.

Wang, H.J., Huang, B., Shi, X.Z., Darilek, J.L., Yu, D.S., Sun, W.X., et al., 2008. Major nutrient balances in small-scale vegetable farming systems in peri-urban areas in China. Nutr. Cycl. Agroecosyst. 81, 203-218.

Wu, M., Huang, S.M., Wen, W., Sun, X.M., Tang, X.Q., Scholz, M., 2011. Nutrient distribution within and release from the contaminated sediment of Haihe River. J. Environ. Sci. 23 (7), 1086-1094.

Xing, G.X., Zhu, Z.L., 2002. Regional nitrogen budgets for China and its major watersheds. Biogeochemistry 57 (58), 405-427.

Zhang, W.L., Wu, S.X., Ji, H.J., Kolbe, H., 2004. The current situation and controlling manures of non-point source pollutions in China. Sci. Agric. Sin. 37, 1008-1017 (in Chinese).
Zhang, Y., Liu, X.J., Fangmeier, A., Gouldingc, K.T.W., Zhang, F.S., 2008. Nitrogen inputs and isotopes in precipitation in the North China Plain. Atmos. Environ. 42 (7), 1436-1448.

Zhang, Y.Y., Liu, J.F., Mu, Y.J., Zhu, X., Pei, S.W., Lun, X.X., et al., 2012. Nitrous oxide emissions from a maize field during two consecutive growing seasons in the North China Plain. J. Environ. Sci. 24 (1), 160-168.

Zhao, B.Z., Zhang, J.B., Flury, M., Zhu, A.N., Jiang, Q.A., Bi, J.W., 2007. Groundwater contamination with NO3-N in a wheat-corn cropping system in the North China Plain. Pedosphere 17 (6), 721-731.

Zhao, R.F., Chen, X.P., Zhang, F.S., 2009a. Nitrogen cycling and balance in winter-wheat-summer-maize rotation system in Northern China Plain. Acta Pedol. Sin. 46 (4), 684-697.

Zhao, T.Q., Xu, H.S., He, Y.X., Tai, C., Meng, H.Q., Zeng, F.F., et al., 2009b. Agricultural non-point nitrogen pollution control function of different vegetation types in riparian wetlands: a case study in the Yellow River wetland in China. J. Environ. Sci. 21, 933-939. 